\title{
PROBLEMS OF APPLICATION OF INNOVATIVE PEDAGOGICAL TECHNOLOGIES IN PRESCHOOL EDUCATION
}

\author{
Yorkinoy Khashimova Ismailovna \\ Researcher Of Tashkent State Pedagogical University, Uzbekistan
}

\section{ABSTRACT}

Preschool education has its own history of the emergence and development of a technological approach to the educational process, including teaching. From the history of our educational institutions, from the research of our scientists, it is clear that the development of this approach to the educational process can be divided into 3 stages. In the first stage, the teaching process is carried out only by the teacher, the experiences and knowledge accumulated by humanity are given to the student only through the teacher. In the second phase, textbooks and manuals began to be published. Didactic materials to help the teacher emerged. In the third stage, the teaching technology was enriched in terms of content: technical means for teachers and students, teaching machines were added, the concept of programmed learning emerged. New approaches have begun to emerge to help increase the effectiveness of education.

KEYWORDS:- Preschool education, innovation, pedagogy, methodology, technology, problem.

\section{INTRODUCTION}

The technological approach to the problem of raising the efficiency of education appeared in the 30s of the last century. During this period, the concept of "pedagogical technique" appeared in the specialized literature and was seen as a set of methods and tools aimed at a clear and effective organization of teaching. , radio, control means, methods of their use are equated with pedagogical technologies.

In the mid-1950s, there was a movement in world pedagogy to organize the educational process in a unique "technological" way. As a result, the technology of pedagogical methods, the theoretical and practical foundations of teaching technology began to emerge. In 1961, the journal "Pedagogical Technology" was published in the United States. In 1964, the journal "Pedagogical Technology and Program Education" was published in England, in 1965 in Japan, and in 1971 in Italy "Pedagogical Technology".

UNESCO has been publishing the bulletin "Pedagogical Technologies" of the International Bureau of Education since 1971, and the Russian Federation has been publishing the journal "School Technologies" since 1997.

By the 70s and 80 s of the 20th century, the design and production of a variety of teaching aids and subject-specific teaching aids had become one of the necessary conditions. Without them, it became clear that advanced methods 
CURRENT RESEARCH JOURNAL OF PEDAGOGICS 2(10): 01-06, October

2021 DOI: https://doi.org/10.37547/pedagogics-crjp-02-10-01

ISSN 2767-3278

(C)2021 Master Journals

Crossref do) 81 Google

Accepted 07th October, 2021 \& Published $12^{\text {th }}$ October, 2021

and forms of teaching would be ineffective, and the quality of education could not be ensured. This need necessitated a systematic study of the theoretical and practical aspects of pedagogical technologies by the 1990s. In particular, Russian scientists have published a number of works in this area. In particular, V.M. Clarin's "Pedagogical technology in the process",

V.P. Bespalko's book "Slagaemxe pedagogicheskoy tehnologii" is the result of large-scale research in this area.

Self-pertinent questions arise: Why do we know so little about the worldwide achievements in this area of pedagogical science? Why is the necessary knowledge about pedagogical technology now provided in educational institutions? Why is there not enough pedagogical literature on the subject, albeit in very small quantities?

In accordance with the Decree of the President of the Republic of Uzbekistan adopted in March 1992, the basis for the selection of entrants to higher education institutions of the Republic by means of tests and the introduction of pedagogical tests in the education system was laid. Special research on the problems of pedagogical technology has begun. The essence of pedagogical technology, its definition and role in the field of pedagogical education was first interpreted in 1993 in the journal "People's Education" by N. Saidakhmedov). Currently, a number of scientists are conducting effective research on the theoretical foundations of pedagogical technologies and their application in practice. Of these, the research work of $\mathrm{RH}$ Juraev, UN Nishonaliev, MS Saidakhmedov, BL Farberman, K. Ishmatov, H. Abdukarimov, K. Zaripov, T. Nazarova deserves special mention. The analysis of scientific research conducted in Uzbekistan shows that today in the Republic the study of the theoretical and practical bases of pedagogical technologies, their perfection and their application in the educational process are considered to be measures of national importance. While one group of our experts recognizes that pedagogical technologies are the need of the hour, as well as a new modern direction, and recommends their application in the educational process with national characteristics, the second group of experts believes that the only way to overcome the crisis in education - emphasize the need to use goggles and create its perfection or to ensure that they give the desired result in different conditions. Experts of the third direction argue that pedagogical technology is a prerequisite for the evolution of education, its theoretical and practical foundations, concepts, the creation of mechanisms for adaptation to market relations, the need to look at education as the main policy. However, it is possible to point out a number of problems in this area that need to be addressed. In particular, it is necessary to clearly define the role of pedagogical technology in the current multi-level system of education, to develop its theoretical and practical basis within a single system. Manuals, developments, methodical instructions, necessary literature in Uzbek language are areas that need to be addressed. It is necessary to create promising, modern, modern technical means and determine their place and function in the system of educational technology. It is necessary to form the skills of educators, teachers, educators to use pedagogical technologies, to improve their skills, to provide ample opportunities for the dissemination of work experience of effective professionals, to create scientific and practical schools on pedagogical technologies.

Thus, a technological approach to teaching emerged in the 1930s. Extensive research has been conducted in all developed countries of the world. Although the country has made significant progress in the field of education, during the Soviet era, this area was strongly condemned as 
a "bourgeois" direction, and research and practice were banned. Successful work is being carried out on the application of technology in the process of teaching and education. The creation of their theoretical and practical basis has become a state order.

The introduction of innovative pedagogical technologies in the educational process is based on certain laws and principles.

Principle is derived from the Latin word "principium", which means basis, initial state, governing idea, generalized requirement. The principles of pedagogical technologies are the general norms and requirements to be followed in order to achieve high results in the implementation of the projected educational process. In determining them, the following factors are taken into account:

1) Educational purpose that meets the requirements of the existing society;

2) Objective laws of the didactic process;

3) Conditions for the implementation of the educational process (N. Saidakhmedov. New pedagogical technologies, 2003, pp. 82-92).

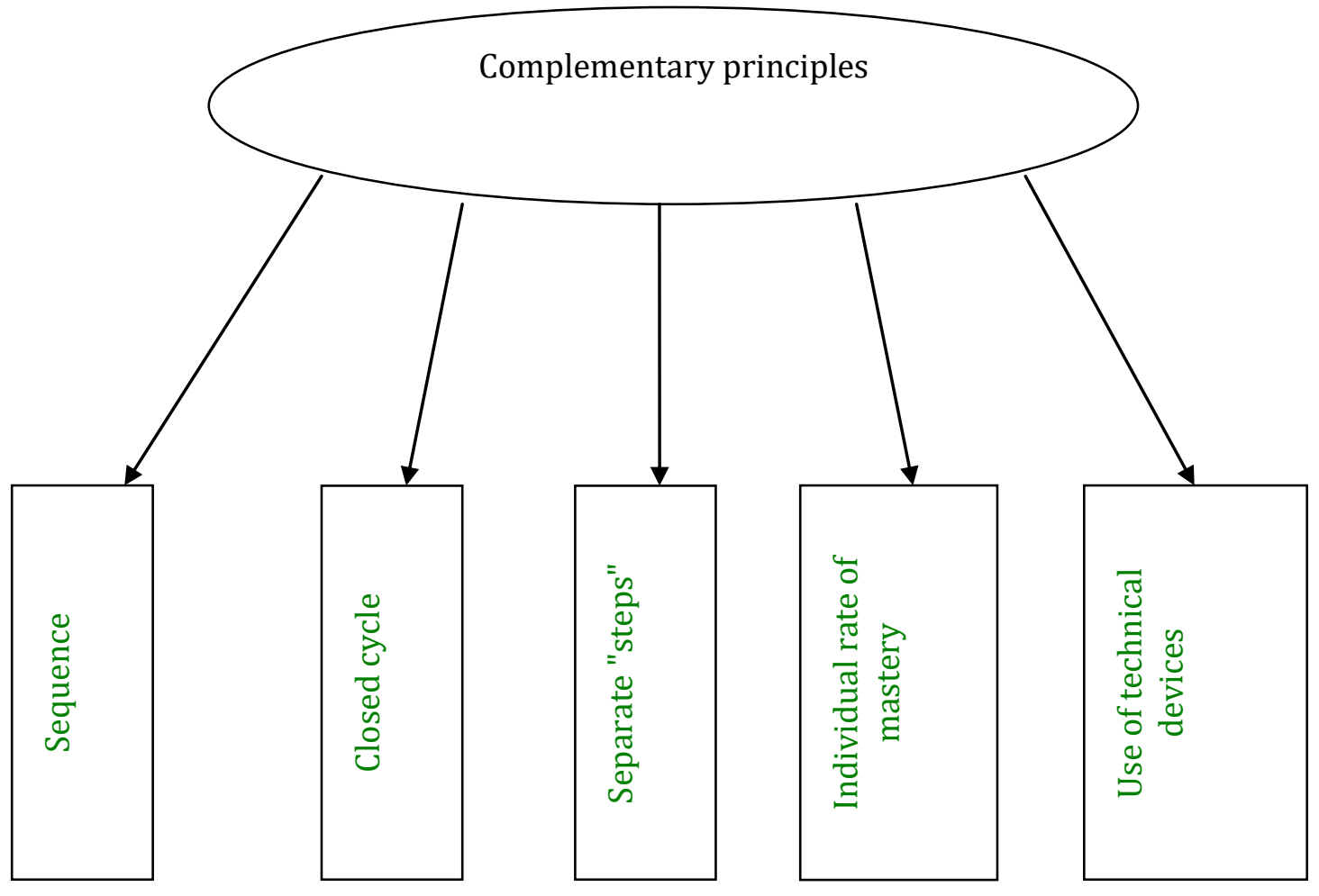

The principle of integrity of pedagogical technology. This principle requires that when creating a technology project, all elements of the pedagogical system are interconnected and interdependent, that is, strictly define the purpose of education (why and why?), The 
CURRENT RESEARCH JOURNAL OF PEDAGOGICS 2(10): 01-06, October

2021 DOI: https://doi.org/10.37547/pedagogics-crjp-02-10-01

ISSN 2767-3278

(C)2021 Master Journals

Crossref do: 81 Google

Accepted 07th October, 2021 \& Published $12^{\text {th }}$ October, 2021

content of the learning process (what?), Organizational forms (how?), facilitate the selection and selection of teaching methods and tools (using what?). it should also allow the effectiveness of the didactic process to be determined depending on the skill level of the teacher.

The principle of integrity denies the possibility of updating or modifying one of the elements that make up pedagogical technology, not touching the rest. For example, it is not possible to change the purpose of education and leave its content or teaching process outdated. Today, profound changes and reforms are taking place in the public education system of the republic. First, the purpose of education has been renewed - it is necessary to form a free-thinking citizen, a wellrounded person. Second, this social order, in turn, leads to a radical restructuring of educational content, the creation of new textbooks and curricula. Third, the new content of education requires tools that accelerate the process of transmitting information to students within a certain period of time. Since then, the creation of new pedagogical and information technologies is a cross-cutting task for scientists. Everyone involved in pedagogical work must understand these problems and take a creative approach to the educational process.

Pedagogical technologies involve the preliminary design of the educational process and the subsequent implementation of this project in the classroom. Therefore, an important principle of pedagogical technology is the principle of predesign of the future educational process. This, of course, requires creative activity from the teacher. The designed technology should be introduced within the time allotted to the subject. Learning time is an important indicator in the pre-construction of pedagogical technology and the teacher must take it into account. It is very important that the projected didactic process is appropriate for the level of mastery of the students in the class and understandable to all. Only then will the final result be achieved.

One of the principles of pedagogical technology is the principle of flexibility. This principle expands the scope of application of pedagogical technologies. The technology designed on this or that topic should have the property of flexibility, at least within the boundaries of the science departments. The teacher will have the opportunity to change or redesign the structure of the didactic process on the subject of science in accordance with the diagnostic purpose, with minimal effort and time. V.P. Analyzing the results of scientific research of Bespalko, B.Skinner, N.D.Nikandrov, N.F.Talizina, B.L.Farberman and others, the following principles of pedagogical technology can be distinguished (K.Ishmatov, Advanced pedagogical technologies, Namangan, 2000, pp. 62-66):

1. Creating a rigid sequence of devices, systems that control the learning activities of students. Devices that control students' learning activities work on the basis of a program pre-designed by a teacher or methodologist (methodologist). Therefore, they only control pre-programmed situations. In the management of students' cognitive activity - the teacher, with the help of a machine (automatic) and in combination with them, it is necessary to design the effective use of self-management.

2. Organize the management of the learning process for each part of the cognitive activity of students in a closed cycle (cyclical). In doing so, it takes into account not only the direct transmission of information to students, but also the receipt of information from them - feedback.

3. The third principle is the use of special steps in the transmission of educational material, revealing its essence. Fulfillment of this requirement will ensure that the program 
CURRENT RESEARCH JOURNAL OF PEDAGOGICS 2(10): 01-06, October

2021 DOI: https://doi.org/10.37547/pedagogics-crjp-02-10-01

ISSN 2767-3278

(C)2021 Master Journals

\section{Crossref do) 8 Google}

Accepted 07thOctober, 2021 \& Published $12^{\text {th }}$ October, 2021

material is understandable to all.

4. The fourth principle is that the individual rate of assimilation is called dsb. Adherence to this principle ensures full mastery of the learning material by all students (albeit at different times). At the same time, it is necessary to choose the most appropriate learning material for each student - uiing mental (perception, attention, thinking) and to determine the trajectory of learning that is acceptable to him.

5. The use of special technical devices in the educational process is the fifth principle of pedagogical technology. A special technical device is a technical device that performs each training step (information, operation, feedback, control).

The above principles define the specific features of pedagogical technology as a didactic system. But they do not reflect all aspects of the organization of the learning process. In pedagogical technology, traditional teaching and all the principles of didactics are used as a special case (consciousness and activity, demonstration, the connection of theory with practice, continuity in teaching, comprehensibility of teaching and thoroughness of knowledge). The principles of pedagogical technology and general didactic principles complement and enrich each other.

Rules of pedagogical technology. In the technological approach to teaching, great emphasis is placed on the interdependence of previously acquired and new knowledge. K.P. McWard argues that the accuracy of the knowledge acquired depends on the strength and scale of that connection. If there is no connection, memorization of the study material being studied does not form knowledge either. If the pieces of new and old information, as well as the connections between them, are strong (rich), then they are divided into those with strong knowledge.
The highest level of availability of these links is made according to the following rules of pedagogical technology:

1. The principle of "equivalent practice". The actions of the teacher in the teaching process and the learning actions set out in his final test must be carried out in exactly the same conditions.

2. The rule of "analog practice". Students can practice similar movements in the learning process, as required by the test (exam).

3. The rule of "knowing the result". The result of each control should be communicated to the student as soon as possible. This rule is also used in the training programmed by $B$. Skinner and $\mathrm{E}$. Thorndike.

The principle of "positive reinforcing reactions". Every achievement of the student should be noticed and encouraged by the teacher in a timely manner. Misconduct of students is not punished. words should motivate them to work.

One of the most important issues of innovative activity is the personality of the teacher: he must be an innovator, a productive creative person, a wide range of interests, a rich inner world, a vengeance for pedagogical innovation.

Innovative activity consists of motivational, technological and reflective parts.

The preparation of the teacher for this activity takes place in two directions: the formation of innovative readiness to perceive innovation and teaching to act in a new way.

In the organization of innovative activities, the cognitive activity of students and its management is of particular importance.

The study of pedagogical processes of innovation processes, functions, mechanisms and technologies of its implementation and management principles allows to organize the educational process on the basis of achievements 
CURRENT RESEARCH JOURNAL OF PEDAGOGICS 2(10): 01-06, October

2021 DOI: https://doi.org/10.37547/pedagogics-crjp-02-10-01

ISSN 2767-3278

(C)2021 Master Journals

Crossref do) 81 Google

Accepted 07th October, 2021 \& Published 12 ${ }^{\text {th }}$ October, 2021

of modern pedagogical and psychological sciences.

\section{REFERENCES}

1. Muslimov N.A., Koysinov O.A. Organization of independent education in the training of vocational education teachers. - $\mathrm{T}$.: TDPU named after Nizami. Methodical manual. 2006.

2. Sayidaxmedov N. "Principles of new pedagogical technology", "Ma'orif" newspaper № 85, October 27, 1995, pages $1-3$.

3. Yuldashev J.G. "New pedagogical technologies" (directions, problems, solutions) - "Start. education", 1999, № 6, pages 2-5.

4. Qosimov, A.X., Kholikova F. "Pedagogical skills and pedagogical technologies" Tashkent, TUIT 2004.

5. Golish L.V. "Modern educational technologies: content, design and implementation" Express manual T. TASIS, 2001.-59 pages.

6. www.tdpu.uz

7. www.pedagog.uz

8. www.Ziyonet.uz 